\title{
Multifunctional alkalophilic a-amylase with diverse raw seaweed degrading activities
}

\author{
Xiaoqian Gu${ }^{1,2}$, Liping Fu ${ }^{1}$, Aihong Pan ${ }^{1}$, Yuanyuan Gui ${ }^{3}$, Qian Zhang ${ }^{1}$ and Jiang $\mathrm{Li}^{1,2,4^{*}}$
}

\begin{abstract}
Uncultured microbes are an important resource for the discovery of novel enzymes. In this study, an amylase gene (amy2587) that codes a protein with 587 amino acids (Amy2587) was obtained from the metagenomic library of macroalgae-associated bacteria. Recombinant Amy2587 was expressed in Escherichia coli BL21 (DE3) and was found to simultaneously possess a-amylase, agarase, carrageenase, cellulase, and alginate lyase activities. Moreover, recombinant Amy2587 showed high thermostability and alkali resistance which are important characteristics for industrial application. To investigate the multifunctional mechanism of Amy2587, three motifs (functional domains) in the Amy2587 sequence were deleted to generate three truncated Amy2587 variants. The results showed that, even though these functional domains affected the multiple substrates degrading activity of Amy2587, they did not wholly explain its multifunctional characteristics. To apply the multifunctional activity of Amy2587, three seaweed substrates (Grateloupia filicina, Chondrus ocellatus, and Scagassum) were digested using Amy2587. After $2 \mathrm{~h}, 6 \mathrm{~h}$, and $24 \mathrm{~h}$ of digestion, $121.2 \pm 4 \mu \mathrm{g} / \mathrm{ml}, 134.8 \pm 6 \mu \mathrm{g} / \mathrm{ml}$, and $70.3 \pm 3.5 \mu \mathrm{g} / \mathrm{ml}$ of reducing sugars were released, respectively. These results show that Amy 2587 directly and effectively degraded three kinds of raw seaweeds. This finding provides a theoretical basis for one-step enzymatic digestion of raw seaweeds to obtain seaweed oligosaccharides.
\end{abstract}

Keywords: Metagenomic, a-amylase, Multifunctional enzyme, Enzymatic digestion

\section{Introduction}

$\alpha$-Amylases hydrolyze their substrate by breaking the $\alpha-1,4$-glycosidic bonds in starch molecules releasing glucose, maltose, and oligosaccharide chains as the products (Gupta et al. 2003; Kandra 2003; Rajagopalan and Krishnan 2008). This enzymatic process is one of the earliest to be applied industrially for the production of sugars. $\alpha$-amylases are also common in animals, plants, and microorganisms (Souza and Magalhães 2010; Yang et al.2010; Kandra 2003).

Traditionally, enzymes were believed to have high selectivity or specificity for their substrates and reactions (Dan 2020). However, enzymes with cross-reactivity or promiscuity have been discovered and characterized (Liu et al. 2016; Khersonsky et al. 2006; Pocker and Stone 1965),

\footnotetext{
*Correspondence: lijiang@fio.org.cn

${ }^{4}$ Key Lab of Ecological Environment Science and Technology, The First Institute of Oceanography, SOA, Qingdao 266061, China

Full list of author information is available at the end of the article
}

and increasing numbers of multifunctional enzymes that can hydrolyze various substrates to produce oligosaccharides have been reported.Multifunctional enzymes (also called moonlighting enzymes or promiscuous enzymes) may be a common mechanism of communication and cooperation between different functions and pathways (Carbonell 2011; Jeffery 2003a, b; Jeffery and Constance 2003; Huberts and Klei 2010). Two important characteristics of moonlighting proteins are multiple functions and independency of each function (Huberts and Klei 2010; Cheng et al. 2012). To date, many multifunctional $\alpha$-amylase have been reported, such as, $\alpha$-amylase Amy63, possessing agarase, carrageenase activity was reported from marine bacterium Vibrio alginolyticus 63 (Liu et al. 2016) and $\alpha$-amylase Amy19, possessing agarase, carrageenase, and cellulase activity was obtained from Fosmid genomic library of hot spring bacterium Bacillus BI-19 (Li et al. 2017).
Springer Open
C The Author(s) 2021. Open Access This article is licensed under a Creative Commons Attribution 4.0 International License, which permits use, sharing, adaptation, distribution and reproduction in any medium or format, as long as you give appropriate credit to the original author(s) and the source, provide a link to the Creative Commons licence, and indicate if changes were made. The images or other third party material in this article are included in the article's Creative Commons licence, unless indicated otherwise in a credit line to the material. If material is not included in the article's Creative Commons licence and your intended use is not permitted by statutory regulation or exceeds the permitted use, you will need to obtain permission directly from the copyright holder. To view a copy of this licence, visit http://creativecommons.org/licenses/by/4.0/. 
Multifunctional enzymes are beneficial to living organisms since they expand the biological functions of an organism without the burden of an expanding genome (Jeffery 1999). Moreover, multifunctionality can provide a switch point in biochemical or signaling pathways to enable organisms to better adapt to their environment (Jeffery 2004). However, the multifunctional mechanism was still underexplored. Previously study showed a bifunctional enzyme from the hyperthermophilic bacterium Caldicellulosiruptor bescii, has two catalytic domain, which are responsible for different function, respectively (Ye et al. 2012), but most of reported multifunctional enzymes only have one catalytic domain, which can play multifunction simultaneously (Huy et al. 2013; Xue et al. 2015; Yang et al. 2015). To identify the possible functional domain responsible for the multifunctional property of Amy63, three successive conserved domains were deleted one by one, even though the result showed that GH70 homologs might play an important role in the multifunctionality of Amy63, but the exact relationship between catalytic domain and the multifunctionality of Amy63 need to be elucidated further (Liu et al. 2016).

Marine algae have been used extensively in medicine, cosmetics, and food, mostly because of the abundant polysaccharides that they contain. Furthermore, algal oligosaccharides have been found to specifically inhibit viruses (Cáceres et al. 2000; Ji et al. 2010), tumors (Hiroishi et al. 2001), and the coagulation process (Alban et al. 2002). Thus, new methods for obtaining oligosaccharides are of interest in several fields. Complex polysaccharides, such as agar, alginates, and carrageenans, are largely present as cell wall components of seaweeds, where they promote structural integrity and shield the host from pathogens and predators. Traditional methods to prepare oligosaccharides include hydrolysis by acids, oxidation, radiation, microwave, and enzymatic digestion (Duan et al. 2016), but an initial step was required to extract polysaccharide substrates from seaweeds before enzymatic degradation, which can cause high energy consumption. Therefore, considering efficiency and cost, the multifunctional enzyme that can directly and effectively degrade raw seaweeds to obtain seaweed oligosaccharides is very attractive for use in industry and a technologically feasible approach with environmental and economic advantages.

Compare with screening the activities of proteins isolated from culturable microbes, uncultured microbes have long been considered as an important resource for the discovery of novel enzyme. Recently, the application of metagenomic technologies to explore marine environments has provided a new way to screen for novel enzymes, especially those produced by uncultured microbes (Tian et al. 2012; Bhattacharyya et al. 2014). In this study, we report a novel multifunctional $\alpha$-amylase
(Amy2587) with agarase, carrageenase, cellulase, and alginate lyase activities that we discovered by screening a macroalgae-associated bacteria metagenomic library. The purified Amy2587 was characterized and its multifunctional mechanism was explored by deleting three motifs in its sequence to obtain truncated proteins. The study will provide a potential method for one-step enzymatic digestion to prepare seaweed oligosaccharides directly from raw seaweed.

\section{Materials and methods}

\section{Construction of the metagenomic library}

Macroalgae samples (Grateloupia filicina, Chondrus ocellatus, and Scagassum) were collected from Halmahera Island $\left(0^{\circ} 36^{\prime} \mathrm{N}, 127^{\circ} 52^{\prime} \mathrm{E}\right)$, Indonesia. The samples were washed with sterilized seawater, then cut into pieces and placed in a sterile tube. Sterile water was added and shaken three times with a vortex oscillator for 2 min each time. Then, sterile filter membranes $(50 \mathrm{~mm}, 0.22-\mu \mathrm{m}$ pore size) were used to collect the bacteria for later use. A FastDNA Spin Kit for Soil (MP Bio) was used to extract the genomic DNA from the collected bacteria samples. After testing, the qualified genomic DNA was sent to Jingneng Biotechnology Co., Ltd. (Shanghai, China) for sequencing, assembly, and functional annotation.

\section{Plasmids, vectors, and substrates}

Plasmid pET-30a (+) and E. coli BL21 (DE3) were purchased from Tiangen Biotech Co., Ltd. (Beijing, China). Soluble starch, agarose, carrageen, sodium cellulose, and alginate were purchased from Sinopharm Group Chemical Reagent Co., Ltd. (Shanghai, china). Grateloupia filicina, Chondrus ocellatus, and Scagassum were collected from Yangkou Beach in Qingdao, China.

\section{Gene synthesis and sequence analysis of Amy2587}

The metagenomic data of the macroalgae-associated bacteria samples were analyzed and the amy2587 gene sequence was obtained by screening the metagenomic library and used as the template to synthesize the target gene. The gene was synthetized by Nanjing Kingsley Biotechnology Co., Ltd. (Nanjing, China). BLAST Search (http://blast.ncbi.nlm.nih.gov/Blast.cgi) were used to identify the amy2587 sequence and the DNAMAN software package (http://www.lynnon.com/) was used for multiple sequence alignment. And the motifs were analyzed using Motif Search (http://www.genome.jp/tools/ motif/).

\section{Expression of amy2587 and purification of Amy 2587}

The amy2587 gene and pET-30(a) were digested by $B a m \mathrm{HI}$ and $\mathrm{XbaI}$ endonucleases respectively, then ligated by T4 DNA ligase to construct the recombinant plasmid 
Amy2587+pET-30(a). The recombinant Amy2587 was expressed in E. coli BL21 (DE3). The obtained transformants were incubated on LB medium $(50 \mu \mathrm{g} / \mathrm{ml}$ kanamycin) with constant shaking at $150 \mathrm{rpm}$ at $37{ }^{\circ} \mathrm{C}$. The Isopropyl- $\beta$-D-thiogalactopyranoside (IPTG) concentration $(0 \mathrm{mmol} / \mathrm{L}, 0.1 \mathrm{mmol} / \mathrm{L}, 0.3 \mathrm{mmol} / \mathrm{L}, 0.5 \mathrm{mmol} / \mathrm{L}$, $0.7 \mathrm{mmol} / \mathrm{L}, 1.0 \mathrm{mmol} / \mathrm{L}$ ) of Amy 2587 was optimized, and the enzyme activity of Amy2587 was determined by DNS method, so as to determine the optimal IPTG concentration of Amy2587. IPTG was added to express the fusion protein when the $\mathrm{OD}_{600}$ reached 0.6. After induction for $16 \mathrm{~h}$ at $16^{\circ} \mathrm{C}$, the cells were collected, placed on ice, and crushed using an ultrasonic cell crushing apparatus.

An Ni-NTA His Tag Kit (Novagen) was used to purify the recombinant Amy2587. First, binding buffer $(10 \mathrm{mM}$ imidazole, $50 \mathrm{mM} \mathrm{NaH} \mathrm{PO}_{4}, 300 \mathrm{mM} \mathrm{NaCl}, \mathrm{pH}$ 8.0) was used to wash the recombinant Amy2587, then elution buffer with different concentrations of imidazole (20 $\mathrm{mM}, 80 \mathrm{mM}, 140 \mathrm{mM}$, and $200 \mathrm{mM}$ ) was used to elute the recombinant Amy2587 (Riera et al. 2003). Finally, the target protein Amy2587 was assessed by sodium dodecyl sulphate-polyacrylamide gel electrophoresis (SDSPAGE) (Blakesley and Boezi 1977).

\section{Substrate specificity of Amy 2587}

To determine the multifunctionality of Amy2587, we studied its substrate specificity. $100 \mu \mathrm{L}$ purified Amy2587 $(0.2 \mathrm{mg} / \mathrm{mL})$ and $900 \mu \mathrm{L}$ substrate $(0.1 \%$ soluble starch, $0.1 \%$ agarose, $0.1 \%$ carrageen, $0.1 \%$ sodium cellulose, and $0.1 \%$ alginate) were incubated for $40 \mathrm{~min}$ at $50{ }^{\circ} \mathrm{C}$, and the Amy2587 activity was measured by the 3,5-dinitrosalicylic acid (DNS) method (Chi et al. 2014). One unit of enzyme activity was defined as the amount of enzyme that can catalyze the release of $1 \mu \mathrm{mol}$ of reducing sugar per minute.

\section{Characterization of Amy2587}

To determine the effect of $\mathrm{pH}$ on Amy2587 activity, $100 \mu \mathrm{L}$ purified Amy2587 (0.2 mg/mL) and $900 \mu \mathrm{l}$ substrate $(0.1 \%$ soluble starch, $0.1 \%$ agarose, $0.1 \%$ carrageen, $0.1 \%$ sodium cellulose, and $0.1 \%$ alginate) were incubated in different buffer systems from $\mathrm{pH} 4.0-11.0 \mathrm{pH}$ 4.0-7.0, $\mathrm{Na}_{2} \mathrm{HPO}_{4}$-citric acid; $\mathrm{pH}$ 7.1-8.9, Tris-HCl; $\mathrm{pH}$ 9.0-10.6, glycine- $\mathrm{NaOH}$ ) for $40 \mathrm{~min}$ at $50{ }^{\circ} \mathrm{C}$. Amy 2587 activity was determined by the DNS method. The highest detected enzyme activity was defined as $100 \%$.

To determine the effect of temperature on Amy 2587 activity, $100 \mu \mathrm{L}$ purified Amy2587 $(0.2 \mathrm{mg} / \mathrm{mL})$ and $900 \mu \mathrm{L}$ substrate $(0.1 \%$ soluble starch, $0.1 \%$ agarose, $0.1 \%$ carrageen, $0.1 \%$ sodium cellulose, and $0.1 \%$ alginate) were incubated at $10{ }^{\circ} \mathrm{C}, 20^{\circ} \mathrm{C}, 30{ }^{\circ} \mathrm{C}, 40^{\circ} \mathrm{C}, 50{ }^{\circ} \mathrm{C}, 60^{\circ} \mathrm{C}, 70{ }^{\circ} \mathrm{C}$, and $80^{\circ} \mathrm{C}$ for $40 \mathrm{~min}$. The highest detected enzyme activity was defined as $100 \%$.

To determine the thermostability of Amy2587, $100 \mu \mathrm{L}$ purified Amy2587 $(0.2 \mathrm{mg} / \mathrm{mL})$, which had been preincubated at $40{ }^{\circ} \mathrm{C}, 50{ }^{\circ} \mathrm{C}$, and $60{ }^{\circ} \mathrm{C}$ for 0 to $24 \mathrm{~h}$, and $900 \mu$ l substrate $(0.1 \%$ soluble starch, $0.1 \%$ agarose, $0.1 \%$ carrageen, $0.1 \%$ sodium cellulose, and $0.1 \%$ alginate) were incubated for $40 \mathrm{~min}$. The highest detected enzyme activity was defined as $100 \%$.

To determine the effect of metal ions $(2 \mathrm{mM})$ on Amy2587, metal cations $\left(\mathrm{Sr}^{2+}, \mathrm{Ni}^{2+}, \mathrm{Ca}^{2+}, \mathrm{Ba}^{2+}, \mathrm{Mn}^{2+}\right.$, $\mathrm{Mg}^{2+}, \mathrm{Fe}^{2+}, \mathrm{Fe}^{3+}, \mathrm{K}^{+}, \mathrm{Cu}^{2+}, \mathrm{Na}^{+}$) were added to the corresponding reaction mixtures and incubated for $40 \mathrm{~min}$ at $50{ }^{\circ} \mathrm{C}$ and $\mathrm{pH}$ 7.0, the standard assay conditions. The enzyme activity in the absence of metal ions was defined as $100 \%$.

\section{Kinetic parameters assay}

The concentrations of the five substrates in the assay system were changed, and changes in the enzymatic reaction rates were measured under the standard assay conditions. The Lineweaver-Burk double-reciprocal method (Morrison 2002) was used to obtain the kinetic parameters and determine the kinetic behaviors of Amy2587.

\section{Variant assay of Amy 2587}

In order to disclose the possible functional domain responsible for the multifunctional property of Amy2587, the potential three functional domains ( $\alpha$-amylase_N, $\alpha$-amylase, and Glyco_hydro_66) (Fig. 1) were found by motif search. Then the truncated genes without these functional domain, named amy2587a (1428 bp), amy 2587b (918 bp), and amy2587c (1491 bp), were synthetized by Nanjing Kingsley Biotechnology Co., Ltd. (Nanjing, China). Truncates were constructed and heterologously expressed in E. coli BL21 cells.

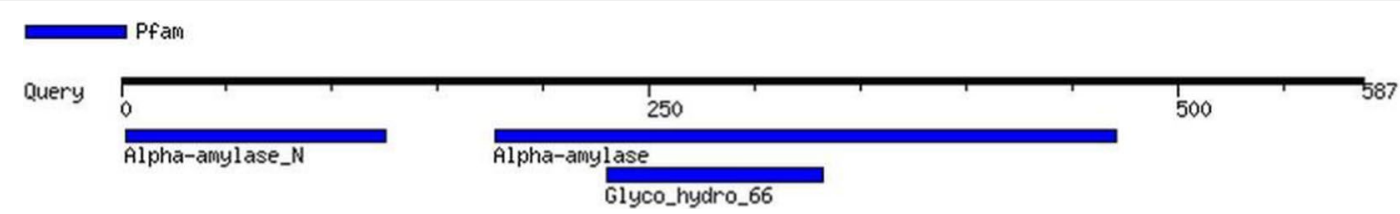

Fig. 1 Sequence analysis of the a-amylase Amy2587. The Pfam motifs are indicates by blue line 


\section{Raw seaweeds digestion using Amy2587}

We employed one-step enzymatic digestion method to obtain oligosaccharides directly from raw seaweed using the novel multifunctional $\alpha$-amylase Amy2587 as follows. Purified enzyme solution $(0.2 \mathrm{mg} / \mathrm{mL})$ was added to artificial seawater containing $2 \%(\mathrm{w} / \mathrm{v})$ of dried red seaweeds, Grateloupia filicina, which mainly produces carrageenan, and Chondrus ocellatus, which mainly produces agar, and dried brown seaweed, Scagassum, which mainly produces alginate. The reaction mixtures were incubated for $0.25 \mathrm{~h}, 0.5 \mathrm{~h}, 1 \mathrm{~h}, 2 \mathrm{~h}, 6 \mathrm{~h}, 12 \mathrm{~h}$, and $24 \mathrm{~h}$ at $50{ }^{\circ} \mathrm{C}$ under the constant shaking at $150 \mathrm{rpm}$. The ability of Amy 2587 to digest the three raw seaweed substrates was demonstrated by measuring the reducing sugar content using the 3,5-dinitrosalicylic acid (DNS) method (Chi et al. 2014).

\section{GenBank accession number}

The complete open reading frame of Amy2587 has been deposited in the GenBank database under accession number MW839461.1.

\section{Results}

Sequence analysis of Amy2587

A novel amylase gene amy 2587 was screened from the metagenomic analysis of macroalgae-associated bacteria. The amy2587 gene was 1785 -bp long and coded a 587-amino acid long protein with a theoretical molecular weight of $67.46 \mathrm{kDa}$. Sequence analysis (Fig. 1) showed that the encoded protein had three Pfam motifs: $\alpha$-amylase_N, $\alpha$-amylase, and Glyco_hydro_66. And the Amy2587 protein sequences were compared with those of the reported amylase (Fig. 2): WP_011201572.1, WP_105980757.1 and WP_032731646.1 showed that the deduced amino acid sequence of amy2587 had high similarity (78-100\%). Based on multiple sequence comparison, Amy2587 had 12 active sites: His209Tyr211-His251-Met296-Asp329-Val330-Glu358-Trp360His424-Asp425-Asp469-Arg473 and 3 catalytic sites: Asp329-Glu358-Asp425.

\section{Expression of amy2587 and purification of Amy2587}

We optimized the IPTG concentration $(0 \mathrm{mmol} / \mathrm{L}, 0.1$ $\mathrm{mmol} / \mathrm{L}, 0.3 \mathrm{mmol} / \mathrm{L}, \quad 0.5 \mathrm{mmol} / \mathrm{L}, 0.7 \mathrm{mmol} / \mathrm{L}, 1.0$

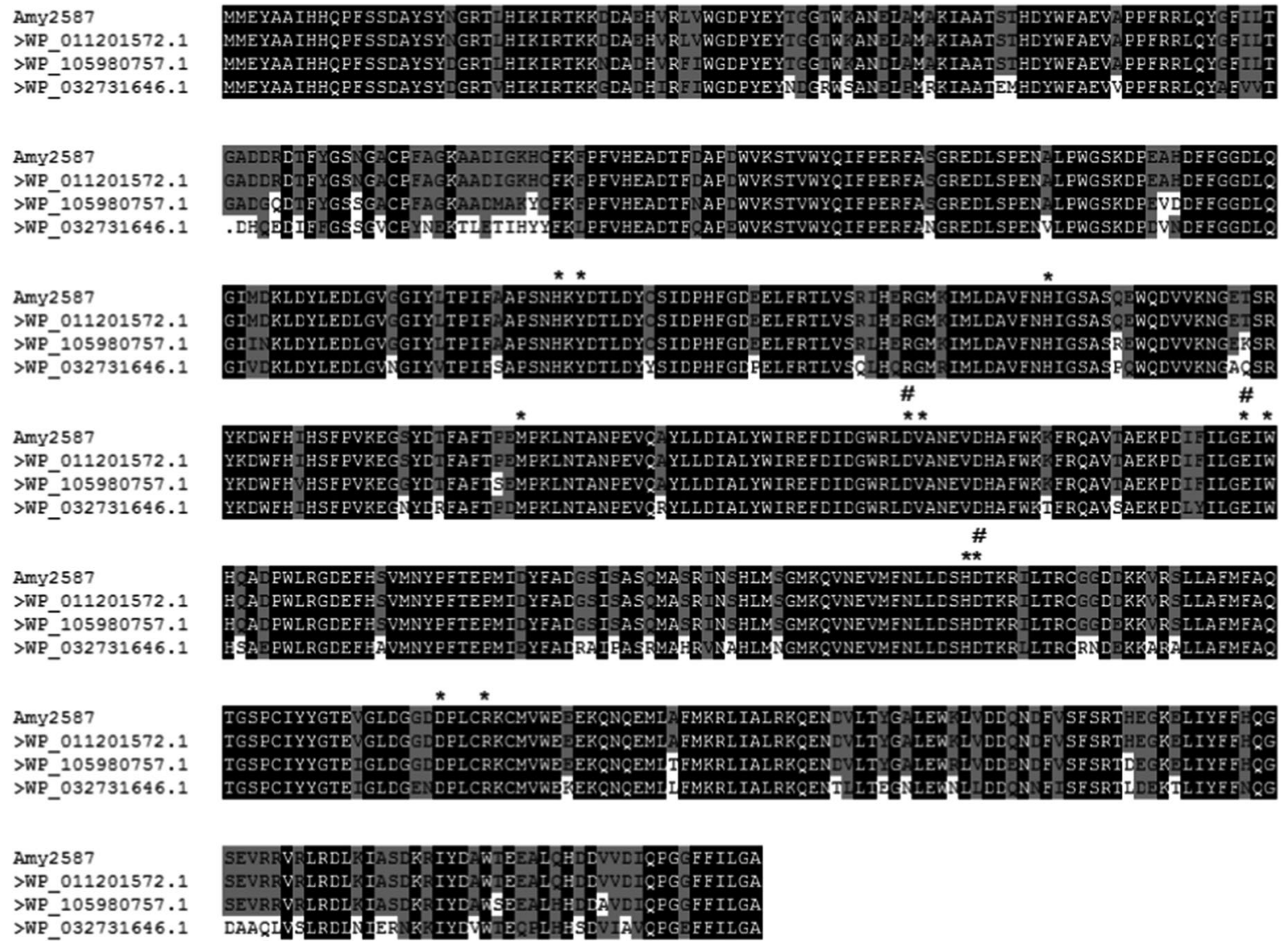

Fig. 2 Multiple sequence comparison of the a-amylase Amy2587 
$\mathrm{mmol} / \mathrm{L}$ ) for protein expression and found that $0.5 \mathrm{mM}$ was optimum level determined by DNS method. The SDS-PAGE analysis (Fig. 3) showed that a single target band of protein (approximate $68 \mathrm{kDa}$ ) was purified when the concentration of the target protein in the imidazole eluent was $80 \mathrm{mM}$. Compared with Amy 2587 without induction, the expression level of Amy2587 with IPTG induction $(0.5 \mathrm{mM})$ was significantly increased from the SDS-PAGE result (Fig. 3), which confirmed the correct expression of amy 2587 in $E$. coli BL21 cells.

\section{Multifunctionality of recombinant Amy2587}

The purified Amy2587 exhibited specific activity levels of $63.38 \pm 0.02 \mathrm{U} / \mathrm{mg}, 18.37 \pm 0.04 \mathrm{U} / \mathrm{mg}, 18.22 \pm 0.02 \mathrm{U} /$ $\mathrm{mg}, 14.51 \pm 0.03 \mathrm{U} / \mathrm{mg}$, and $17.74 \pm 0.03 \mathrm{U} / \mathrm{mg}$ toward five substrates (soluble starch, agar, carrageen, sodium cellulose, and alginate) (Table 1). These results confirmed that Amy2587 was a multifunctional $\alpha$-amylase that possessed amylase, agarase, carrageenase, cellulase, and alginate lyase activities simultaneously.

\section{Biochemical characterization of recombinant Amy2587}

The highest activities for the $\alpha$-amylase, agarase, carrageenase, cellulase, and alginate lyase were obtained at $50{ }^{\circ} \mathrm{C}$, with about $50 \%$ initial activity retained at $40-60{ }^{\circ} \mathrm{C}$ (Fig. 4a). Notably, Amy2587 showed high thermostability with almost $85 \%$ of its original activity retained after incubation at $50{ }^{\circ} \mathrm{C}$ for $4 \mathrm{~h}$. With increasing incubation

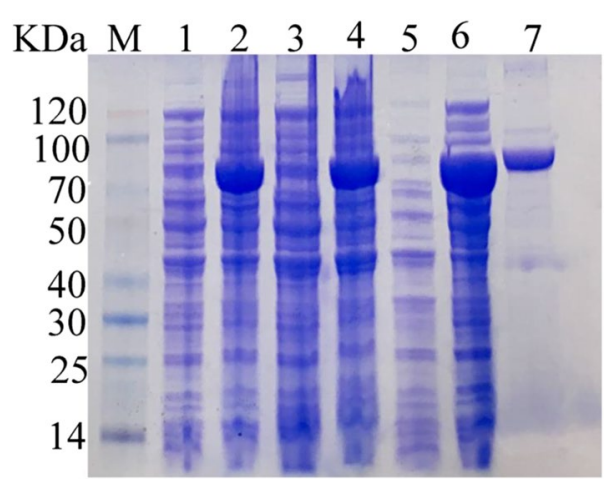

Fig. 3 SDS-PAGE analysis of the target protein Amy2587. M: Protein marker; Lane 1: Whole-cell of recombinant Escherichia coli BL21 (DE3) cells harboring pET-30(a)-amy2587 before induction; Lane 2: Whole-cell of recombinant Escherichia coli BL21 (DE3) cells harboring PET-30(a)-amy2587 after induction; Lane 3: Supernatant of recombinant Escherichia coli BL21 (DE3) cells harboring pET-30(a)-amy2587 before induction; Lane 4: Supernatant of recombinant Escherichia coli BL21 (DE3) cells harboring pET-30(a)-amy2587 after induction; Lane 5: Precipitate of recombinant Escherichia coli BL21 (DE3) cells harboring pET-30(a)-amy2587 before induction; Lane 6: Precipitate of recombinant Escherichia coli BL21 (DE3) cells harboring pET-30(a)-amy2587 after induction; Lane 7: Purified Amy2587
Table 1 Specific activity levels (U/mg) of Amy2587 and three truncated Amy2587 variants with different substrates

\begin{tabular}{lllll}
\hline Substrates & Amy2587 & Amy2587a & Amy2587b & Amy2587c \\
\hline Soluble & $63.38 \pm 0.02$ & $44.30 \pm 0.03$ & $37.43 \pm 0.03$ & $30.26 \pm 0.01$ \\
starch & $18.38 \pm 0.04$ & $5.86 \pm 0.02$ & $5.82 \pm 0.03$ & $9.16 \pm 0.01$ \\
Agar & $18.22 \pm 0.02$ & $9.09 \pm 0.02$ & $5.17 \pm 0.02$ & $6.76 \pm 0.03$ \\
Carrageen & $14.51 \pm 0.03$ & $8.68 \pm 0.05$ & $9.79 \pm 0.01$ & $7.88 \pm 0.02$ \\
Sodium cel- & $17.44 \pm 0.03$ & $9.87 \pm 0.03$ & $5.73 \pm 0.02$ & $9.89 \pm 0.02$ \\
lulose & & & & \\
Alginate & & & & \\
\hline
\end{tabular}

The truncated Amy2587 variants, Amy2587a, Amy2587b, and Amy2587c have had the a-amylase_N motif, a-amylase, and Glyco_hydro_66 motifs deleted, respectively

times, the enzyme activity gradually decreased, but was still more that $60 \%$ after $24 \mathrm{~h}$ of incubation (Fig. $4 \mathrm{~b}$ ).

The highest activities for the $\alpha$-amylase, agarase, carrageenase, cellulase, and alginate lyase were obtained at pH 10.0 (Fig. 4c). Notably, Amy2587 showed high multifunctional activity, with almost $70 \%$ of its original activity retained after incubation at $\mathrm{pH} 11.0$ for $24 \mathrm{~h}$. The results indicated that Amy2587 was an alkaliphile enzyme, and such enzymes play important roles in industrial biotransformations.

The metal ions had different effects on Amy2587 activity (Fig. $4 \mathrm{~d}$ ). $\mathrm{Mn}^{2+}, \mathrm{Fe}^{2+}, \mathrm{K}^{+}$, and $\mathrm{Na}^{+}$had different degrees of promoting effects, and $\mathrm{Sr}^{2+}, \mathrm{Ni}^{2+}, \mathrm{Ca}^{2+}, \mathrm{Ba}^{2+}$, $\mathrm{Mg}^{2+}$, and $\mathrm{Fe}^{3+}$ had different degrees of inhibiting effects on Amy2587 activity. Notably, $\mathrm{Cu}^{2+}$ dramatically reduced Amy2587 activity, and all the multifunctional enzyme activities were almost completely lost.

\section{Kinetic parameters of Amy2587}

The $K_{\mathrm{m}}$ values of Amy2587 for the five substrates, soluble starch, agarose, carrageen, sodium cellulose, and alginate, were $4.06 \pm 0.04 \mathrm{mg} / \mathrm{mL}, 10.10 \pm 0.03 \mathrm{mg} / \mathrm{mL}, 12.25 \pm$ $0.04 \mathrm{mg} / \mathrm{mL}, 11.54 \pm 0.06 \mathrm{mg} / \mathrm{mL}$ and $14.91 \pm 0.06 \mathrm{mg} /$ $\mathrm{mL}$, respectively. The $V_{\max }$ values of Amy 2587 for the five substrates, soluble starch, agarose, carrageen, sodium cellulose, and alginate, were $47.16 \mu \mathrm{mol} / \mathrm{mL} \cdot \mathrm{min}, 78.74$ $\mu \mathrm{mol} / \mathrm{mL} \cdot \mathrm{min}, 93.46 \mu \mathrm{mol} / \mathrm{mL} \cdot \mathrm{min}, 87.71 \mu \mathrm{mol} / \mathrm{mL} \cdot \mathrm{min}$ and $109.89 \mu \mathrm{mol} / \mathrm{mL} \cdot \mathrm{min}$, respectively (Fig. 5).

\section{Variant assay of Amy2587}

To further understand the multifunctionality of Amy2587, three functional domains coded in the amy 2587 sequence were knocked out. The truncated Amy2587 variants amy2587a (1428 bp), amy2587b (918 bp), and $\operatorname{amy} 2587 c$ (1491 bp) were successfully expressed and purified. The enzymatic activity of Amy2587 was higher than that of the three truncated Amy2587 variants (Amy2587a, Amy2587b, and 

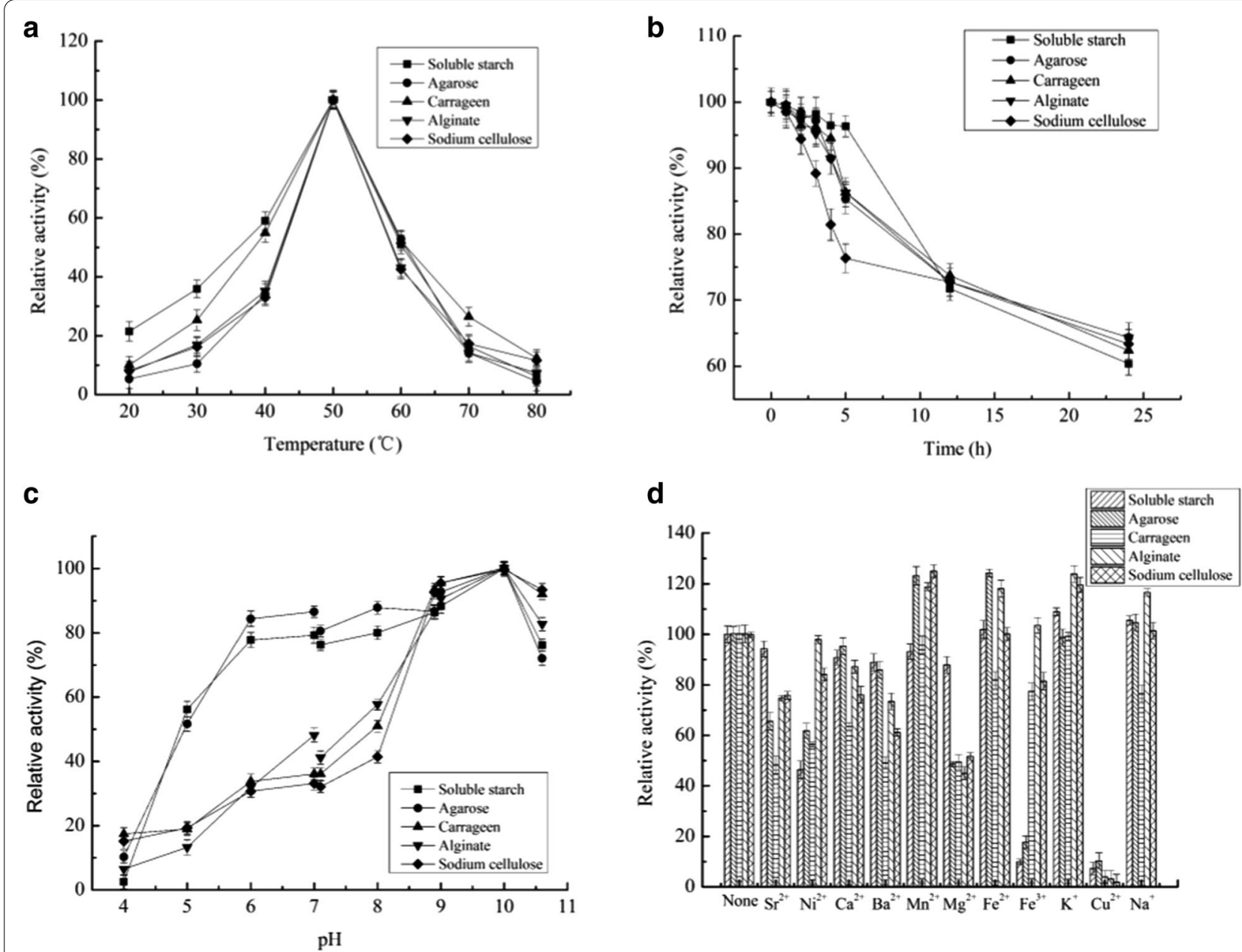

Fig. 4 Effects of temperature, $\mathrm{pH}$ and metal ions on the activity of Amy 2587 with different substrates. $\mathbf{a}$ Effects of temperature on the activity of Amy2587 with different substrates; $\mathbf{b}$ Thermostability of Amy2587 at different temperatures and time points with different substrates; $\mathbf{c}$ Effects of pH on the activity of Amy 2587 with different substrates; $\mathbf{d}$ Effects of metal ions and metal salts on the activity of Amy 2587 with different substrates

Amy2587c) for all five substrates, soluble starch, agarose, carrageen, sodium cellulose, and alginate (Table 1).

\section{Digestion of raw seaweeds by Amy2587}

Amy2587 showed high ability to digest raw seaweeds after incubating for $0.25 \mathrm{~h}, 0.5 \mathrm{~h}, 1 \mathrm{~h}, 2 \mathrm{~h}, 6 \mathrm{~h}, 12 \mathrm{~h}$, and $24 \mathrm{~h}$ under the standard assay conditions (Fig. 6). During the degradation of the seaweed substrates, Grateloupia filicina, Chondrus ocellatus, and Scagassum, Amy2587 released $121.2 \pm 4 \mu \mathrm{g} / \mathrm{ml}, 134.8 \pm 6 \mu \mathrm{g} / \mathrm{ml}$, and $70.3 \pm$ $3.5 \mu \mathrm{g} / \mathrm{ml}$ of reducing sugars after $12 \mathrm{~h}, 6 \mathrm{~h}$, and $24 \mathrm{~h}$, respectively (Fig. 7).

\section{Discussion}

Active screening of culturable microorganisms is still the main method used to obtain polysaccharide-degrading enzymes (Marjolaine et al. 2015). However, the recent explosion of metagenomic data has provided a new way of screening for polysaccharide-degrading enzymes, especially novel enzymes produced by unculturable microorganisms. In this study, an amylase gene amy 2587 was screened from metagenomic library from macroalgae-associated bacteria.

Recombinant Amy2587 was expressed in E. coli BL21 (DE3) and characterized. To determine the multifunctionality of Amy2587, we studied its substrate specificity and found that it exhibited strong $\alpha$-amylase, agarase, carrageenase, cellulase, and alginate lyase activities, simultaneously. Other amylases have been reported to have multifunctional functions. For example, the multifunctional amylase Amy440 produced by Aquimarina agarilytica ZC1 was reported to show amylase and agarase activities (Lin et al. 2017); the multifunctional amylase Amy63 produced by Vibrio alginolyticus 63 was reported to show amylase, agarase and carrageenase activities (Liu et al. 2016); and the multifunctional amylase Amy19 

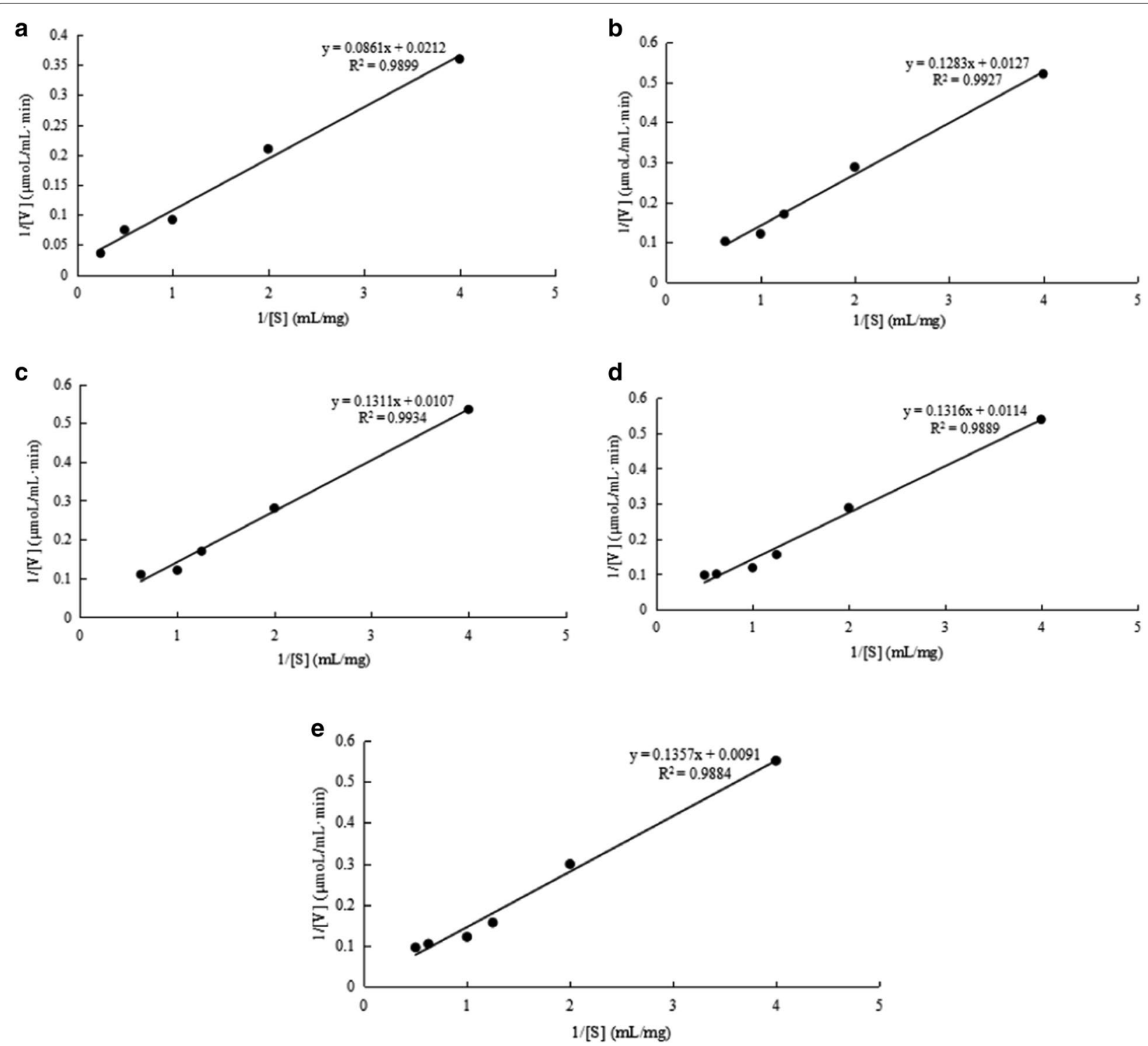

Fig. 5 Kinetic parameters of Amy2587 with different substrates. a Amylase activity; b Agarase activity; c Carrageenase activity; d Cellulase activity; e Alginate lyase activity

produced by Bacillus BI-19 was reported to show agarase, carrageenase, and cellulase activities ( $\mathrm{Li}$ et al. 2019). To the best of our knowledge, Amy2587 is the first multifunctional enzyme found to have five enzyme activities at the same time. Considering efficiency and cost, enzymes that exhibit amylase, agarase, carrageenase, cellulase, and alginate lyase activities would have wide industrial applications (Chai et al. 2020).

Amy2587 showed high thermostability and was alkalophilic, which are important characteristics for enzymes that play important roles in biotransformations and industrial production because polysaccharide substrates are colloidal and viscous at low temperatures or high concentrations, which impedes the efficiency of binding between enzymes and substrates ( $\mathrm{Li}$ et al. 2019).

The effects of the metal ions on Amy2587 activity were not identical. In particular, $\mathrm{Cu}^{2+}$ dramatically reduced Amy2587 activity, and all the multifunctional activities were almost lost. Similar results for the effect of $\mathrm{Cu}^{2+}$ have been reported for other enzymes, including Amy19 (Li et al. 2019) in the GH70 family and AgaXa (Xie et al. 2013) in the GH118 family. $\mathrm{Cu}^{2+}$ decreases enzyme activity by binding with the thiol group in the active site of enzymes (Murashima et al. 2002).

The $K_{\mathrm{m}}$ value of Amy2587 with soluble starch was similar to the $K_{\mathrm{m}}$ value for the amylase from Thermus 


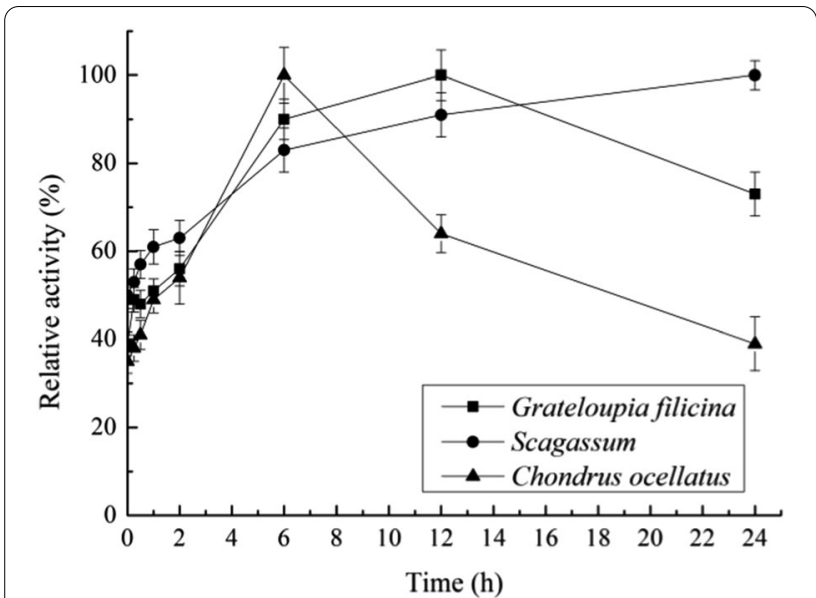

Fig. 6 Relative activity of Amy2587 during degradation of three seaweed substrates, Grateloupia filicina, Chondrus ocellatus, and Scagassum

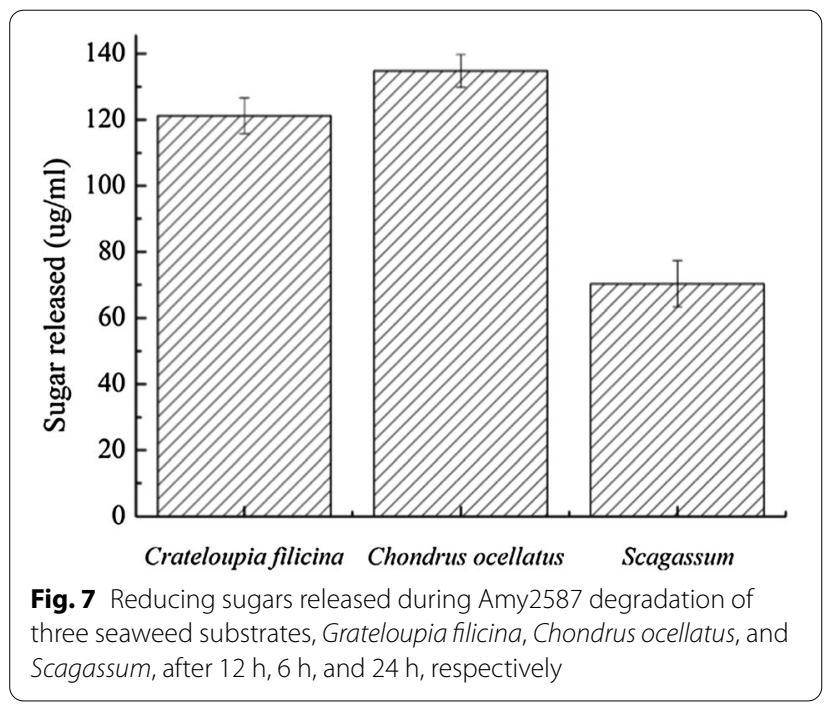

filiformis 0rk A2 (5.0 mg/ml) (Egas et al. 1998), and lower than the $K_{\mathrm{m}}$ values for the amylases from Bacillus alcalophilus JN21 (9.64 mg/mL) (Yang et al. 2011) and Thermococcus HJ21(45.0 mg/mL) (Wang et al. 2008). The $K_{\mathrm{m}}$ value of Amy2587 with agarose was similar to the $K_{\mathrm{m}}$ value for the agarase obtained from Catenovulum sp. X3 $(10.50 \mathrm{mg} / \mathrm{mL})$ (Xie et al. 2013), and lower than the $K_{\mathrm{m}}$ values for the agarases from Agarivorans albus OAY02 $(15.38 \mathrm{mg} / \mathrm{mL}$ ) (Yang et al. 2014) and Saccharophagus degradans $2-40(41.90 \mathrm{mg} / \mathrm{mL})$ (Dong et al. 2016). The $K_{\mathrm{m}}$ value of Amy2587 with carrageen was higher than the $K_{\mathrm{m}}$ values for carrageenases from Vibrio. sp. $(2.54 \mathrm{mg} / \mathrm{mL})$ (Zhu et al. 2016) and Pseudoalteromonas sp. (9.80 mg/ $\mathrm{ml}$ ) (Ma et al. 2010), and lower than the $K_{\mathrm{m}}$ value for the carrageenase from Shewanella sp. Kz7 (716.8 mg/ $\mathrm{ml}$ ) (Wang et al. 2015). The $K_{\mathrm{m}}$ value of Amy2587 with sodium cellulose was higher than the $K_{\mathrm{m}}$ values for the cellulases from Bacillus subtilis SU40 (1.97 mg/mL) (Asha et al. 2014) and Bacillus subtilis I15 (3,59 mg/mL) (Yang et al. 2010a, b). The $K_{\mathrm{m}}$ value of Amy2587 with alginate was higher than the $K_{\mathrm{m}}$ value for the alginate lyase from Vibrio furnissii $\mathrm{H} 1$ ( $2.28 \mathrm{mg} / \mathrm{mL}$ ) (Zhu et al. 2018). These results show that Amy2587 had good affinity for all five substrates.

To further understand the multifunctionality of Amy2587, three motifs, Alpha-amylase_N, Alphaamylase, or Glyco_hydro_66, in the Amy2587 sequence were deleted. The results showed that these functional domains affected the multiple substrates degrading activity of Amy2587, but the multifunctional characteristics were not fully explained. The Amy2587 activity decreased to different degrees in the truncated enzymes, but the amylase activity was not lost and, although the agarase, carrageenase, cellulase, and alginate lyase activities were affected, the multifunctional activities of Amy2587 remained.

The gene sharing model is often used to explain why an enzyme maintains promiscuity, where a gene with a given function is recruited for a different, moonlighting function without any changes in the coding region (Piatigorsky et al. 1989). Furthermore, evolution of the active sites of existing enzymes that promiscuously bind the substrates can allow new enzymatic capabilities to be generated (Khersonsky et al. 2006). Amy2587 originate from metagenomic library of associated-bacteria of macroalgae surface, which were collected from coastal zone near hot springs of Ambon island, Indonesia. Usually, such environment has high temperature but low nutrient content. Liu et al. (2016) hypothesized that these marine bacteria have evolved their existing amylase to allow usage of other carbohydrates like agar and carrageenan as the carbon source when they must survive in a harsh environment without enough starch.

To apply the multifunctional activity of Amy2587, three seaweed substrates (Grateloupia filicina, Chondrus ocellatus and Scagassum) were digested using Amy2587. The amount of reducing sugars released by Amy 2587 digestion was much higher than the amount released by Microbulbifer strain CMC-5 digestion of red seaweed for 10 days $(60 \mu \mathrm{g} / \mathrm{mL})$ (Jonnadula et al. 2009) and higher than the amount released by Bacillus sp. SYR4 digestion of seaweed for $120 \mathrm{~h}(24 \mu \mathrm{g} / \mathrm{mL})$ (Kang and Kim 2015), but lower than the amount released by bacteria DM1, DM5, and DM15 utilization of Sargassum after $72 \mathrm{~h}(503.3 \pm 17.5 \mu \mathrm{g} / \mathrm{mL}, 491.6 \pm 20 \mu \mathrm{g} / \mathrm{mL}$, and 376.6 $\pm 16 \mu \mathrm{g} / \mathrm{mL}$ respectively). These results suggest that the novel multifunctional $\alpha$-amylase Amy2587 has high 
potential for seaweed degradation. To our knowledge, this is the first report of an enzyme, not bacteria, that can directly and effectively degrade different kinds of raw seaweeds to obtain seaweed oligosaccharides. Therefore, eco-friendly degradation for the production of oligosaccharides directly from raw seaweed may be possible using Amy2587. This finding provides a theoretical basis for one-step enzymatic digestion of raw seaweeds.

\section{Acknowledgements}

We thank Margaret Biswas, PhD, from Liwen Bianji, Edanz Editing China (www. liwenbianji.cn/ac), for editing the English text of a draft of this manuscript.

\section{Authors' contributions \\ $J L$ and $X G$ designed the experiment, interpreted the data, and finalized conclusions. XG, AP and LF conducted experimental work and drafted the manuscript. YG and QZ assisted with experiments. All authors read and approved the final manuscript.}

\section{Funding}

This research was supported by the Key Research and Development Program of Shandong Province, China (2018GHY115013), Impact and Response of Antarctic Seas to Climate Change (RFSOCC2020-2022).

\section{Availability of data and materials}

The complete open reading frame of Amy 2587 has been deposited in the GenBank database under accession number MW839461.1.

\section{Declarations}

\section{Ethics approval and Consent to participate}

This article does not contain any studies with human participants or animals performed by any of the authors. All listed authors have approved the manuscript before submission, including the names and order of authors.

\section{Consent for publication}

All authors have reviewed the final version of the manuscript and approve it for publication.

\section{Competing interests}

The authors declare no competing interest.

\section{Author details}

${ }^{1}$ Key Lab of Ecological Environment Science and Technology, First Institute of Oceanography, Ministry of Natural Resources, 266061 Qingdao, China.

${ }^{2}$ CAS and Shandong Province Key Laboratory of Experimental Marine Biology, Center for Ocean Mega-Science, Institute of Oceanology, Chinese Academy of Sciences, 266071 Qingdao, China. ${ }^{3}$ College of Environmental Science and Engineering, Qingdao University, 266071 Qingdao, China. ${ }^{4}$ Key Lab of Ecological Environment Science and Technology, The First Institute of Oceanography, SOA, Qingdao 266061, China.

Received: 9 July 2021 Accepted: 12 October 2021

Published online: 20 October 2021

\section{References}

Alban S, Schauerte A, Franz G (2002) Anticoagulant sulfated polysaccharides: Part I. Synthesis and structure-activity relationships of new pullulan sulfates. Carbohyd Polym 47:267-276

Asha BM, Sakthivel N (2014) Production, purification and characterization of a new cellulase from Bacillus subtilis that exhibit halophilic, alkalophilic and solvent-tolerant properties. Ann Microbiol 64:1839-1848

Bhattacharyya PN, Tanti B, Barman P, Jhn DK (2014) Culture-independent metagenomic approach to characterize the surface and subsurface soil bacterial community in the Brahmaputra valley, Assam, North-East
India, an Indo-Burma mega-biodiversity hotspot. World J Microb Biot 30:519-528

Blakesley RW, Boezi JA (1977) A new staining technique for proteins in polyacrylamide gels using coomassie brilliant blue G250. Anal Biochem 82:580-582

Cáceres PJ, Carlucci MJ, Damonte EB, Matsuhiro B, Zuñiga EA (2000) Carrageenans from chilean samples of Stenogramme interrupta (phyllophoraceae): structural analysis and biological activity. Phytochemistry 53:81-86

Carbonell P, Lecointre G, Faulon JL (2011) Origins of specificity and promiscuity in metabolic networks. J Biol Chem 286:43994-44004

Chai S, Zhang X, Jia Z, Xu X, Feng Z (2020) Identification and characterization of a novel bifunctional cellulase/hemicellulase from a soil metagenomic library. Appl Microbiol Biot. https://doi.org/10.1007/s00253-020-10766-X

Cheng XY, Huang WJ, Hu SC, Zhang HL, Wang H, Zhang JX, Lin HH, Chen YZ, Zou Q, Ji ZL (2012) A global characterization and identification of multifunctional enzymes. PLoS One 7:e38979. https://doi.org/10.1371/journal. pone.0038979

Chi WJ, Da YP, Seo YB, Yong KC, Lee SY, Hong SK (2014) Cloning, expression, and biochemical characterization of a novel gh16 $\beta$-agarase AgaG1 from alteromonas sp. GNUM-1. Appl Microbiol Biotechnol 98:4545-4555

Dan ST (2020) Enzyme promiscuity and evolution in light of cellular metabolism. FEBS J 287:1260-1261

Dong Q, Ruan LW, Shi H (2016) A $\beta$-agarase with high pH stability from Flammeovirga sp. SJP92. Carbohyd Res 432:1-8

Duan F, Yu Y, Liu Z, Tian L, Mou H (2016) An effective method for the preparation of carrageenan oligosaccharides directly from eucheuma cottonii using cellulase and recombinant K-carrageenase. Algal Res 15:93-99

Egas MCV, Costa MSD, Cowan DA (1998) Extracellulara-amylase from Thermus filiformis Ork A2: purification and biochemical characterization. Extremophiles 2:23-32

Gupta R, Gigras P, Mohapatra H, Goswami VK, Chauhan B (2003) Microbial a-amylases: a biotechnological perspective. Process Biochem 38:1599-1616

Hiroishi S, Sugie K, Yoshida T, Morimoto J, Taniguchi Y, Imai S, Kurebayashi J (2001) Antitumor effects of Marginisporum crassissimum (Rhodophyceae), a marine red alga. Cancer Lett 167:145-150

Huberts DH, Klei IJVD (2010) Moonlighting proteins: an intriguing mode of multitasking. Acta Bioch Bioph Sin 1803:520-525

Huy ND, Thayumanavan P, Kwon T, Park SM (2003) Characterization of a recombinant bifunctional xylosidase/arabinofuranosidase from Phanerochaete chrysosporium. J Biosci Bioeng 116:152-159

Jeffery CJ (1999) Moonlighting proteins. Trends Biochem Sci 24:8-11

Jeffery CJ (2003a) Moonlighting proteins: old proteins learning new tricks. Trends Genet 19:415-417

Jeffery CJ (2003b) Multifunctional proteins: examples of gene sharing. Ann Med 35:28-35

Jeffery CJ (2004) Molecular mechanisms for multitasking: recent crystal structures of moonlighting proteins. Curr Opin Struct Biol 14:663-668

Ji J, Wang LC, Wu H, Luan H (2010) Bio-function summary of marine oligosaccharides. Int J Biol 3:74-86

Jonnadula RC, Verma P, Shouche YS, Ghadi SC (2009) Characterization of Microbulbifer Strain CMC-5, a new biochemical variant of Microbulbifer elongatus type strain DSM6810T isolated from decomposing seaweeds. Curr Microbiol 59:600-607

Kandra L (2003) a-Amylases of medical and industrial importance. J Mol Struct 1:487-498

Kang S, Kim JK (2015) Reuse of red seaweed waste by a novel bacterium, Bacillus sp. SYR4 isolated from a sandbar. World J Microb Biot 31:209-217

Khersonsky O, Roodveldt C, Tawfik DS (2006) Enzyme promiscuity: evolutionary and mechanistic aspects. Curr Opin Chem Biol 10:498-508

Li J, Gu XG, Pan AH (2018) Multifunctional a-amylase Amy19 possesses agarase, carrageenase, and cellulase activities. Int J Biol Macromol 126:585-594

Lin BK, Song Y, Lu GY, Zhao M, Zhong M, Zhong HU (2017) Expression and analysis of an amylase with agarase activity from a marine bacterium. Biot Bull 33:125-130

Liu G, Wu SM, Jin WH, Sun CM (2016) Amy63, a novel type of marine bacterial multifunctional enzyme possessing amylase, agarase and carrageenase activities. Sci Rep 6:1-12 
Ma YX, Dong SL, Jiang XL, Li J, Mou HJ (2010) Purification and characterization of kappa-carrageenase from marine bacterium mutant strain Pseudoalteromonas sp. AJ5-13 and its degraded products. J Food Biochem 34:661-678

Marjolaine M, Tristan B, Renee M, Daniel P, Gurvan M, Micheline V (2015) The cultivable surface microbiota of the brown alga ascophyllum nodosum is enriched in macroalgal-polysaccharide-degrading bacteria. Front Microbiol 6:1487-

Morrison JF (2002) Lineweaver-Burk Plot. Encyclopedia of Molecular Biology. Wiley, New York. https://doi.org/10.1002/047120918X.emb0849

Murashima K, Nishimura T, Nakamura Y, Kuga J, Simuda N (2002) Purification and characterization of new endo-1, 4- $\beta$-Dglucanases from Rhisopus oryzae. Enzyme Microb Tech 30:319-326

Piatigorsky J, Wistow GJ (1989) Enzyme/crystallins: gene sharing as an evolutionary strategy. Cell 57:197-199

Pocker Y, Stone JT (1965) The catalytic versatility of erythrocyte carbonic anhydrase. The enzyme-catalyzed hydrolysis of rhonitrophenyl acetate. J Am Chem Soc 87:5497-5498

Rajagopalan G, Krishnan C (2008) Alpha-amylase production from catabolite derepressed Bacillus subtilis KCC103 utilizing sugarcane bagasse hydrolysate. Bioresource Technol 99:3044-3050

Riera M, Pages M, Issinger OG, Guerra B (2003) Purification and characterization of recombinant protein kinase CK2 from Zea mays expressed in Escherichia coli. Protein Expres Purif 29:0-32

Souza PMD, de Oliveira e Magalhes P (2010) Application of microbial a-amylase in industry-a review. Braz J Microbiol 41:850-861

Tian XP, Long LJ, Wang FZ, Xu Y, Li J, Zhang J, Zhang CS, Zhang S, Li WJ (2012) Streptomyces nanhaiensis sp. nov. a marine streptomycete isolated from a deep-sea sediment. Int J Syst Evol Micr 62:864-868

Wang LN, Li SY, Zhang SL, Li JJ, Yu WG, Gong QH (2015) A new K-Carrageenase CgkS from marine bacterium Shewanella sp. Kz7. J Ocean U China 14:759-763

Wang SJ, Lu ZX, Lu MS, Qin S, Liu HF, Deng XY, Lin Q, Chen JN (2008) Identification of archaeon-producing hyperthermophilic a-amylase and characterization of the a-amylase. Appl Microbiol Biot 80:605-614

Xie W, Lin B, Zhou ZR, Lu GY, Lun JS, Xia CY, Li SK, Hu Z (2013) Characterization of a novel $\beta$-agarase from an agar-degrading bacterium Catenovulum sp. X3. Appl Microbiol Biot 97:4907-4915
Xue X, Wang R, Tu T, Shi PJ, Ma R (2015) The N-terminal GH10 domain of a multimodular protein from Caldicellulosiruptor bescii is a versatile Xylanase/ $\beta$ Glucanase that can degrade crystalline cellulose. Appl Environ Microbiol 81:3823-3833

Yang CH, Huang YC, Chen CY, Wen CY (2010a) Expression of thermobifida fusca thermostable raw starch digesting alpha-amylase in Pichia pastoris and its application in raw sago starch hydrolysis. J Ind Microbiol Biot 37:401-406

Yang DL, Weng HB, Wang MG, Xu WH, Li YZ, Yang HL (2010b) Cloning and expression of a novel thermostable cellulose from newly isolated Bacillus subtilis strain 115. Mol Biol Rep 37:1923-1929

Yang H, Liu L, Li J, Du G, Chen J (2011) Heterologous expression, biochemical characterization, and overproduction of alkaline a-amylase from Bacillus alcalophilus in Bacillus subtilis. Microb Cell Fact 10:77-85

Yang M, Mao X, Liu N, Qiu Y, Xue C (2014) Purification and characterization of two agarases from Agarivorans albus OAY02. Process Biochem 49:905-912

Yang W, Bai Y, Yang P, Luo HY, Huang HQ, Meng K, Shi PJ, Wang YR, Yao (2015) A novel bifunctional GH51 exo-a-l-arabinofuranosidase/endo-xylanase from Alicyclobacillus sp. A4 with significant biomass-degrading capacity. Biotechnol Biofuels 8:1-11

Ye L, Su X, Schmitz G, Moon YH, Zhang J, Mackie RI, Cann IKO (2014) Molecular and biochemical analyses of the GH44 module of CbMan5B/Cel44A, a bifunctional enzyme from the hyperthermophilic bacterium Caldicellulosiruptor bescii. Appl Environ Microbiol 78:7048-7059

Zhu BW, Ning LM (2015) Purification and characterization of a new $\mathrm{k}$-carrageenase from the marine bacterium Vibrio sp. NJ-2. J Microbiol Biotechn 26:255-262

Zhu X, Li X, Hao S, Zhou J, Tan Z, Yuan M, Peng Y, Liu X (2018) Characterization of a novel alginate lyase from marine bacterium Vibrio furnissii H1. Mar Drugs 16:30-39

\section{Publisher's Note}

Springer Nature remains neutral with regard to jurisdictional claims in published maps and institutional affiliations.

\section{Submit your manuscript to a SpringerOpen ${ }^{\circ}$ journal and benefit from:}

- Convenient online submission

- Rigorous peer review

- Open access: articles freely available online

- High visibility within the field

- Retaining the copyright to your article

Submit your next manuscript at $\boldsymbol{\Delta}$ springeropen.com 